\title{
STATE MONOPOLY OF THE RIGHT TO PUNISH AND PRIVATE SECURITY COMPANIES
}

\author{
Qaisar NASRAT
}

\begin{abstract}
Today, political philosophers see the social contract as a symbol of popular satisfaction and the basis of the legitimacy of a democratic government. In political philosophy, it is believed that by entering into a social contract, individuals are deprived of the right to punish offenders and consent to the government to prosecute perpetrators on behalf of them. However, the question is whether this right is an exclusive right of the state, or if the persons who are a party to the social contract transfer it to another person, whether real or legal, that person also has the right to punish. In this regard, two major views of the "instrumental nature of the state" and "the inherent right of the state" have been raised in the practice of punishment. According to the first point, while the people have given satisfaction to the punishment imposed by the government, the government has the right to determine and enforce the sentence, " it is supposed that carry out punishment justice by state is better than any other person. In the second view, however, the state has a role in punitive acts, and acts outside of the state, although are not punishable.

The present paper addresses the issue of monopoly on punishment by the government, what are the limits this right and concludes the monopoly of the right to punish is belongs to the State, but it may authorize certain powers to the privat security companies to execute on its behalf.
\end{abstract}

Keywords: Criminal Justice System, Monopoly of Punishment, National Security, Private Security.

Makalenin Geliș Tarihi: 03.03.2021, Makalenin Kabul Tarihi: 17.06.2021.

*Dr. (nasrat513@gmail.com, ORCID: 0000-0003-4676-8122) 


\section{Introduction}

Human history is full of struggle and wars among power holders. This continued after the emergence of modern states. However, the only legitimate institution that held power here was the state. Modern society and democratic states flourished in a context of transition from feudalism to capitalism, observed in Western Europe between the fifteenth and eighteenth centuries. During this process, there have been substantive transformations in the economy, society, the state and culture. The dissolution of the social and intellectual world of the Middle Ages accelerated in the last quarter of the eighteenth century, known as "the era of revolutions", ${ }^{1}$ converging towards the phenomenon that Max Weber called the "disenchantment of the world". ${ }^{2}$

In the history of modern Western thought, the concept of force (power) is linked to the anthropological presupposition of absolute autonomy of the individual. Anything that would constrain or restrict it in any form could be described as force. In this perspective, it was not possible to distinguish between force, coercion and violence, there was in fact no way to distinguish between legitimate use of force and illegitimate, just and unjust power. ${ }^{3}$

Kant shares the distinction between potestas and potentia, between strength and force. It rejects the identity of the state as pure force, and in the same way as the principle of an institutionalized force. For Kant, the state is par excellence "the unification of a multiplicity of men under the law". ${ }^{4}$ The state is an enterprise of domination of one another by means of the use of force or the threat of its use. Nevertheless, it is a legitimate violence, because allowed by law.

Throughout this historical process, we have witnessed the sedimentation of a tradition in which violence is thought of as a resource of power and domination. The problem then lies not in the violence itself, but rather in the social and public control of his job. Max Weber's formula is also famous. In his essay "The scholar and the political", he says: "Today the relationship between the state and violence is particularly intimate. Historically the most

1 Robert NISBET, "La formación del pensamiento sociológico", Amorrortu, V. 2, Buenos Aires, 1977, available at: https://www.amorrortueditores.com/Papel/9789505182244/La+formaci\%C3\%B3n+del+p ensamiento+ sociol\%C3\%B3gico, 20.03.2020.

2 Max WEBER, "Le savant et le politique", Union Générale d'Editions, Le Monde en 1018, Paris, 1963, p. 29.

C. Colliot-Thélene, Violence et contrainte, Lignes, no: 25, mai 1995, p. 264-278. Ibid., p. 265. 
diverse political groupings - beginning with kin - have all held physical violence for the normal means of power. On the other hand, the contemporary state must be conceived of as a human community which, within the limits of a given territory - the notion of territory being one of its characteristics successfully claims for itself the monopoly of legitimate physical violence." And he continues, "Like all the political groupings that preceded it historically, the state consists of a relationship of domination of man over man based on the means of legitimate violence".

In this perspective, it is necessary to consider that when Max Weber speaks of a legitimate monopoly of violence, he does not argue in any way that any violence used in the name of the state is justifiable. If this were the case, it would be impossible to differentiate the rule of law from the state power that avails itself of the abusive and arbitrary use of force. Under no circumstances can the tolerated violence exceed the limits imposed. These limits are dictated by the foundations that govern domination in modern society. ${ }^{6}$

Within this society, violence considered legitimate is precisely the one whose ends - ensuring the sovereignty of a nation-state or the threatened unity of a society - rest on the law and on legal status. Legitimacy is therefore identified with legality. In this way, the state monopoly of violence does not mean the exclusive exercise of violence, but the exclusive monopoly of the ability to prescribe it and, consequently, to prohibit any private employment or misuse of it. on the part of those who are in principle authorized to use it. Consequently, we find in Weberian thought a strong identification between the notions of power, domination and control of violence. And that is where the birth and functionality of the police, the criminal courts and the prisons reside. They consist of legitimate means of administering social control, the enforcement of penal laws and the imposition of order against any transgression. ${ }^{7}$

This study outlines three issues. First, the definition and explanation of the monopoly of punishment from different perspectives; second, the

5 Weber, 1963: 29.

6 Sérgio ADORNO, "Le monopole étatique de la violence : le Brésil face à l'héritage occidental", Cultures \& Conflits, V.59, automne 2005, p.6

Gewaltmonopol, available at: http://www.krimlex.de/artikel.php?BUCHSTABE=G\&KL $\mathrm{ID}=81,23.03 .2019$.

7 Ibid, p. 6- 7. 
historical development and philosophical background of the monopoly to punish; and third, the place of private security companies in this concept.

\section{State Monopoly of Violence}

State Monopoly on the use of force (Right to Punish, Violence) is one of the main concepts of modern public law.

The concept of the monopoly on the use of force in modern societies stands for the claim of the state to be the only one to exercise physical violence within the framework of existing law. The ability of individual citizens to enforce their natural rights by force is therefore limited to exceptional situations, such as in the right of self-defense. ${ }^{8}$

Violence is considered the prerogative of the state and will be ascribed to it a positive assessment as a necessary element in the construction of social order: the monopoly of violence is instituted with the purpose of establishing or, where appropriate, preserving set of external conditions that safeguard peaceful coexistence, which is related to an essential problem of politics that is war and peace, since the task of achieving exclusivity in the use of force reflects in the constitution of the state the tendency to overcoming the polycentrism of power in favor of a concentration of power in a partially unitary and exclusive instance that conjures the current or imminent threat of returning to a kind of "state of nature" of the society without rules that remains prey of the bellum omnium against omnes, of which Hobbes mentions. Through the monopoly on use of force, the state would establish a scenario to protect the elemental good of life and achieve the minimum objective of a government, which is peaceful coexistence. Because only in a peaceful situation can political power carry out the coordination and organization of the activities of public institutions that are directed to more complex objectives such as the regulation of social life, the division of freedoms, the provision of services public and the redistribution of income. ${ }^{9}$

The term "state monopoly on use of force" commonly means the monopoly of the state on the legitimate exercise of physical coercion..$^{10}$ In his

8 "Gewaltmonopol", Kriminologie-Lexikon (Online), available at: http://www.krimlex.de/artikel.php?BUCHSTABE=G\&KL ID=81, 23.06.2019.

9 Gloria María Gallego GARCÍA, "Sobre el monopolio legítimo de la violencia", Nuevo Foro Penal, No: 66, 2003, págs. 72-120.

10 Andreas FISAHN, "Legitimation des Gewaltmonopols", Kritische Vierteljahresschrift, 2011, p. 4, available at: https://www.nomos-elibrary.de/10.5771/2193-7869-2011-13/legitimation-des-gewaltmonopols-volume-94-2011-issue-1, 12.06.2020. 
lecture "Politics as a Vocation" (1918), the German sociologist Max Weber defines the state as a "human community that (successfully) claims the monopoly of the legitimate use of physical force within a given territory". The monopoly of power means the monopoly on the use of physical coercion. The monopoly of the state in this interpretation seems to be compatible with the distribution to different centers of power in the state - the monopoly is possessed by the state. ${ }^{11}$

The important term of above definition is "legitimate". Because, if people or groups can use violence, it is by no means legitimate. Only the state is empowered to use violence without being denied its legitimacy. This is part of its legal prerogatives. Even when the state allows individuals to use violence (case of self-defense), individuals hold this legitimacy of the state, in the form of delegation. ${ }^{12}$

The concept does not imply that the state is the only actor who actually uses violence, but rather that it is the only actor that can legitimately authorize its use. The State may grant another actor the right to resort to violence without losing its monopoly, as long as it remains the sole source of the right to resort to violence. ${ }^{13}$

Under the state monopoly on use of the force is a comprehensive state law enforcement and enforcement monopoly to understand that only the state's concern for legal peace by assigning law. ${ }^{14}$ According to this, the state alone has the power to exercise physical force. The monopoly of force is an essential feature of the sovereign state. It is an important part of state security and care for the future. The state monopoly on power serves to safeguard public security and order and is a recognized state task of constitutional rank. ${ }^{15}$ Countries constitutions have not expressly regulated the monopoly of power of the state. But Constitutionally, it could be derived from the rule of law and some other articles.

11 Ibid.

12 “L'etat Détient Le Monopole De La Violence Légitime”, La Philo, available at: https://aphilosophie.com/letat-detient-le-monopole-de-la-violence-legitime-weber, 26.06.2019.

13 Yen MAKABENTA, "The death penalty and state monopoly of violence", The Manila Times, July 06 2019, available at: https://www.manilatimes.net/the-death-penalty-andstate-monopoly-of-violence/273191/, 05.04.2019.

14 Stober, "Staatliches Gewaltmonopol und privates Sicherheitsgewerbe - Plädoyer für ein Police-Private-Partnership", NJW, 1997, S. 889.

15 Ibid. 
According to Hobbes, the state refers to salvation from the cruel environment of natural state. In this subject the basic idea is the 'equality'. Hobbes justifies that nature creates people equally in terms of body and mind. ${ }^{16}$

\section{Historical development of Monopoly of Violence}

If two people argue or fight each other, we pick up the phone and call the police- a combination of numbers that almost everyone knows. If troops of a foreign power invade any country, the invaded state would declare war on this power and send out the military army to expel the invaders. A state army for external protection, police and security agencies to provide security on the territory of a state. When the military army and police act as described, they exercise the so-called "monopoly on the use of force".

The idea of the monopoly on the use of force in political philosophy is already old and can already be found some 450 years ago by the French state theoretician Jean Bodin and the English thinker Thomas Hobbes. German sociologist Max Weber coined the term in this country at the beginning of the 20 th century. ${ }^{17}$

The emergence of the monopoly of violence can not be understood as an incident, but as a process. The idea of state sovereignty finds itself at the end of an eventful historical development. In Europe, the monopoly of violence developed after the overcoming of the medieval order, which no monopolized sovereign powers, but a large number of autonomous power holders with their own sovereignty such as clergy, nobility and cities. Also, this development was accompanied by political-philosophical concepts that postulated an omnipotent, absolute power to prevent anarchy, civil war and the law of Faust, starting from a picture of man, which conceived of man's nature as one-sidedly impulsive, selfish and beastly. First, this led to the dictatorial power of the princes, which showed that the monopoly of violence of the state is bearable only if the state authority itself is legally bound. The development of the monopoly of use of force must therefore be accompanied by the separation of powers, so that the three functions of the state - legislation, administration and jurisdiction - are distributed among different, independent state organs, which

6 Thomas HOBBES, Leviathan, Çev. Semih Lim, 4. Bask1, YKY yay., İstanbul, 2004, s. 92. "Das Gewaltmonopol des Staates in Abgrenzung zur sog., Leitkultur", Euradiopa, 24. JUNI 2017, available at: https://euradiopa.wordpress.com/2017/06/24/kommentar-dasgewaltmonopol-des-staates-in-abgrenzung-zur-sog-leitkultur/, 14.06.2019. 
are allowed to act only within the framework of legally assigned competences and according to prescribed rules of law. ${ }^{18}$

In the pre-state era, protection offered only by the group itself. If one them was attacked, the members would protect themselves or the other against the external enemy. If someone violated their unwritten rules, they excluded him. Here the basics were laid for what was later called "blood revenge". What this means is that individual security is ensured solely by the own group by threatening potential evildoers and their groups with counter-violence. Before there were functioning states, people often kept their disputes under themselves. They often resorted to violence. Courts were able to strike a certain balance between the opposing parties, but the enforcement of law was often tied to their own ability to prevail, if necessary, by force.

The first states: The first great empires that emerged between the eighth and second pre-Christian times did not change much in the practice of blood revenge. They saw themselves as responsible for the securing of peace within their borders, but without claiming a state monopoly on the use of force. The role of families, clans, and tribes was strengthened even more because they relied on them to maintain security and order. Thus it remained that families feuded each other and security by the threat of revenge was maintained. Wherever the power of the king was strong enough, the worst excesses of this revenge-based system were curtailed - but in Europe it was fundamentally questioned only in the Middle Ages, through the so-called God's Peace Movement. ${ }^{19}$

The first steps towards the monopoly of force: In this era a so-called God's Peace movement was a religious movement that wanted to prove that people can engage in a society in which they renounce the individual use of force. It originated in the 11th century in the south of France, between the Pyrenees and the Rhône, where the royal power was weak. At diocesan synods and other large gatherings, the nobility was encouraged to pledge by mutual oath to observe the so-called Pax Dei (God's peace). Basically, on Sundays and public holidays, the peace should be maintained. Gradually, an extension of God's peace succeeded. In 1085, Henry IV issued the first Kingdom-wide divine

18“Gewaltmonopol", Kriminologie-Lexikon (Online), available at: http://www.krimlex.de/artikel.php?BUCHSTABE=G\&KL ID=81, 23.06.2019.

19 Jonas GRUTZPALK, "Das Gewaltmonopol des Staates", Bundeszentrale Für Politische Bildung, 14.6.2012, available at: https://www.bpb.de/politik/innenpolitik/inneresicherheit/125721/das-gewaltmonopol-des-staates? $\mathrm{p}=$ all, 07.07.2019. 
peace at the Diet in Mainz, and it became the royal power to enforce this peace. At regular intervals, the nobility had to summon him again. ${ }^{20}$

The sovereign state: Ultimately, making possible a monopoly on the use of state force was made possible by the writings of the Frenchman Jean Bodin (1529-1596) and the Englishman Thomas Hobbes (1588-1679). While Bodin founded the theory of state sovereignty, a power that has no other power over or next to itself, Hobbes made the state monopoly of power conceivable. Bodin was the first to distinguish the function of the sovereign from his family, making it possible to discern a difference between the sovereign state and ruling families. Hobbes explained what the sovereignty of the state should serve: to curb violence and to monopolize it in his hands.

Thomas Hobbes has given his main work titled "Leviathan", in which he argue the fact that the state alone should have the privilege of use of force. In this study Hobbes envisioned state power as a terrible monster, because it was supposed to arouse fear. The state should keep people from avenging themselves with force and violence. ${ }^{21}$ Sibylle Tönnies explains the motive of Hobbes as follows: "Hobbes wanted the state to arouse fear - instead of the fact that man must continue to be afraid of his peers". ${ }^{22}$

Social contract for monopoly on use of force: Although Hobbes made it clear that the Leviathan is the centralized brutal violence. However, he assumed that this state monopoly on use of force ultimately came through the consent of all. In a social contract, he argues, every member of society dismisses his will for force, transfers it to the state, and in return expects the state to ensure security and order. The state is created by the will of its citizens, but goes far beyond the capabilities and opportunities of the individual citizen, said Hobbes. For him, therefore, the state is an " god on earth", which justifies the interests of the people. The state, however, is a man-made body, it is created by a reciprocal contract. ${ }^{23}$

Some critics have accused Hobbes of paving the way for the totalitarian regimes of the 20th century and their dictatorship. According to Sibylle Tönnies: "Because Hobbes always understood the power of the state in the

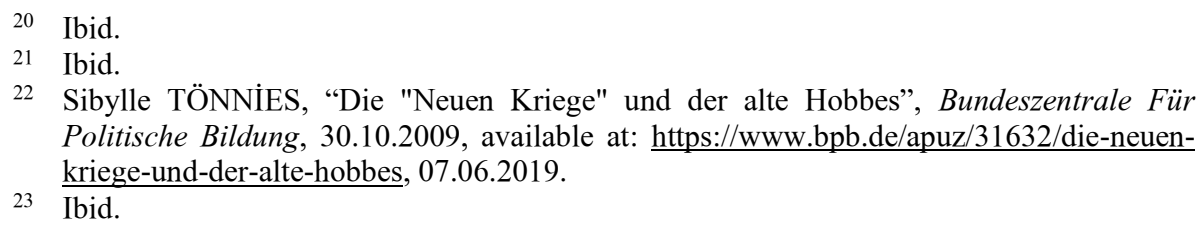


context of the protection-obedience exchange, he could not be regarded as a proponent of totalitarianism". ${ }^{24}$

Locke, Montesquieu und Rousseau: Rule of law: the state needs a limit (border) is an idea that had to be extended to the Hobbes "invention" of the monopoly on use of force. This limit is commonly lays in the laws. Important representatives of this idea were John Locke (1632-1703), Charles-Louis de Montesquieu (1689-1755) and Jean-Jacques Rousseau (1712-1778). While Locke emphasized that the state had the task of specifying natural law in order to make it applicable to human societies, Montesquieu emphasized that the laws must be in accordance with the social situation of the people. From him comes the sentence that can still today be considered as a rule of thumb for the modern constitutional state: "A state can be constructed in such a way that no one is forced to do something that he is not obliged to do by law, and nobody is forced to refrain from something the law permits." It is noteworthy that Jean-Jacques Rousseau, who is at least as important to the philosophical foundation of the modern state as Thomas Hobbes, had a completely opposite understanding of the natural state of man. While Hobbes describes the ongoing state of war of all against all as characteristic of the nature of man, Rousseau, conversely, assumes that it is only the society that turns the bad side of the naturally peaceful man out. Rousseau concluded in his theory that society by property and power had destroyed the natural order of human beings. Rousseau, like Hobbes, also proposes a theory of social contract. What is new about Rousseau is the idea that the laws should correspond to the general will of the people (volonté générale). But laws should be universal and thus ensure security, freedom and order. ${ }^{25}$

The history of the state does not end with the ideas of Hobbes and Rousseau, it is not with the development of the rule of law bound monopoly of power of the nation states. The state has since had to face new challenges, such as the realization that in its totalitarian form it harms its citizens more than it uses. Moreover, the nation states have lost their importance in times of "accelerated globalization". ${ }^{26}$

Thus, the dissolution of the political system of the Middle Age and the replacement of the modern state has been a radical transformation in every

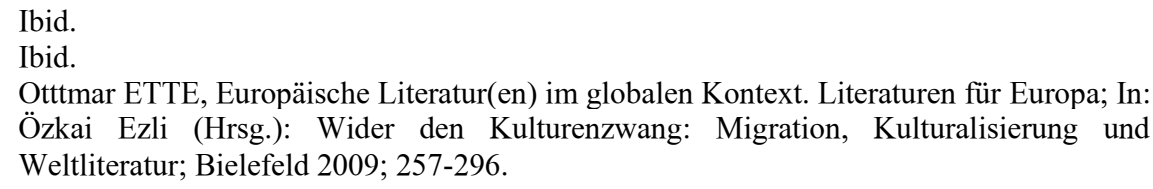


aspect of our life. Because, it bring down the local and sectarian forces, ensure the unity and integrity of the administration and the law, monopolize the means of violence within certain boundaries. It is the birth of the Leviathan, the giant that will keep the social groups struggling with each other within certain limits, create protective customs against the outside, protect the borders and conquer new markets. ${ }^{27}$

\section{Limits of the State Monopoly of Violence}

The state tends to creat a society free from violence. This purification is realizing by the use of state's sovereign authority. The state establishes rules with its sovereign power and ensures that these rules are complied with if necessary.$^{28}$ So the fundamental task of the state is the maintenance of internal and external security.

For a modest reduction of the monopoly of the state by the participation of private, social and financial sectors. ${ }^{29}$ The police are serious about their constitutional mandate, so they must vigorously face future threats to public safety and order. However, the tasks of property and personal protection can hardly be achieved on their own, so that the demand for private security benefits will increase. ${ }^{30}$

This chapter first presents the development of the private security industry in general. Subsequently, the different areas of application of the private security companies are presented and explained. In this context, different views of the boundaries of the outsourcing of state tasks are presented in an excursus. The following is an explanation of possible reasons explaining the increase in the number of private security companies.

\section{Exercise of Sovereign Powers by Private Security Companies}

Another form of security by private security companies is the transfer of original sovereign security tasks to private individuals. These sovereign tasks can only be transferred by way of loan to private persons. ${ }^{31}$

27 SANCAR, Mithat "Devlet Aklı" Kıskacında Hukuk Devleti, İletişim Yayınları, İstanbul, 2000, s. 16-17.

28 Oya BOYAR, “Anayasa Hukuku ve Şiddet”, MÜHF - HAD, C.22, S.1(61), https://dergipark.org.tr/tr/download/article-file/274328, 03.05.2020.

29 Stober, a.a.O., Fn. 8.

30 Felix HAMMER, "Private Sicherheitsdienste, staatliches Gewaltmonopol, Rechtsstaatsprinzip und schlanker Staat", DÖV, 2000, S. 613.

31 Walter, "Bekämpfung der Seepiraterie in: Die Polizei", BT-Drs., 2012, S. 1 (6); 15/5824, S. 6 . 
However, it should be noted that the core area of the state monopoly on the use of force, ie the guarantee of security as a manifestation of the purpose of the state, is not disposable and must remain in the hands of the state. In its core substance, the security purpose of the state is inviolable and, because of its peacekeeping function, inaccessible to privatization. ${ }^{32}$

Criminal monopoly of state is gradually being eroded by the privatization of judicial coercion and public order missions. We no longer count the private policies that dominate the security market especially around sensitive or prestigious places like embassies or airports, while the privatization of prisons is becoming widespread in the United States but also in France. ${ }^{33}$

It is easy for a frightening observer to notice that the private conveyance seems to reconnect with the economy of the Ancien Régime chain, which is leased to entrepreneurs who benefit from it. Is it really desirable that the monopoly of violence of the state can thus generate the economic benefit of private actors? Certainly inherent in the market of security and sovereign missions, is political patronage compatible with the impartiality of the monopoly of state? Punishing is a function too serious to distort the foundations of the state by security ideology and budget constraint. To deplore the increasing privatization of the sovereign tasks of security and justice is less an "ideological stance" than a democratic warning against the generalization of such uses. Question: how to plug the growing gap in the privatization of public security? In certain political and social contexts, this privatization of the sovereign tasks of the state can only be liberticidal. Beyond the sectoral problem of the twelve private security agents who will ensure, year in and year out, the conveyance of detainees between the places of detention and the courthouse, the privatization of the sovereign tasks raises very widely the democratic debate on the institutional nature and the functioning of the judiciary. Criminal ethics is not compatible with private interests. Today it is easy to privatize the convoy of prisoners. Tomorrow, commercial companies may offer other judicial and police services (arrest, police custody, interrogation, etc.) whose advantageous cost could lead the State to further subject its sovereignty to the laws of the market. ${ }^{34}$

\footnotetext{
Porret, 2015.

Ibid.

Ibid.
} 
However, numerous examples are conceivable in the cooperation between state agencies and private security companies in the sense of a security partnership. All these "Police Private Partnership Models" must be classified as permissible if the private security companies are only granted such rights that can be transferred to them by any private individual for selfprotection. ${ }^{35}$ In order to assess the lawfulness, a differentiated assessment is made according to the criteria of public property law. According to this, a distinction is made between the use of private security companies for the protection of property in administrative and public use. While the protection of property is permitted by private security services in the administration (home-based institutions, such as museums), no rights can be transferred to public use items (e.g., pedestrian areas), as this is a non-transferable core police task. $^{36}$

Consequently, in the past, security was increasingly implemented by commercial security firms used to protect individual assets such as the property or life of the right holder. According to the prevailing opinion, this case group presents itself as legally unproblematic. ${ }^{37}$ The admissibility of commercial security in the private sector does not preclude the state monopoly on force. Crucial to the legality of the security by private security companies in this context is that the persons employed have no police powers, so that a sovereign action is excluded. Personal security company personnel are limited in the protection of individual rights to the rights that individuals have to protect their legal interests. Thus, the private security services are entitled only to the private emergency rights of self-defense, emergency, self-help and similar rights. ${ }^{38}$

\section{Conclusion}

Violence as a prerogative of the state began to be analyzed in the late sixteenth and early seventeenth centuries, when modern political philosophy began, on the basis of narrating the emergence of the state as the work of a creative human force through of a pact between free and equal men for the realization of certain practical purposes among which is counted stop the

35 Saipa/Wahlers/Germer, "Gewaltmonopol, Gefahrenabwehrauftrag und private Sicherheitsdienste", $N d s V B l, 2000,285$ ff., (289-290).

36 Ibid.

37 Peilert, "Police-Private-Partnership", DVBl, 1999, 282 ff., 284.

38 Deutscher Bundestag, Einsatz von privaten Sicherheitsfirmen im Hinblick auf das Gewaltmonopol, Ausarbeitung. WD 3 - 3000 - 236/12, 28. August 2012, s. 7. 
social bellicosity. ${ }^{39}$ Hobbes, who lived in that period, created one of the stories about the origin of the state on the basis of the succession of war, daily practice that unfolds in all dimensions, between individual or groups. Deterring them from violence, depriving them of access to military resources will be one of the essential tasks attributed to the state, whose constitution will be assimilated to the emergence of a political organization that monopolizes power in a monopolistic manner and, with it, use of violence. ${ }^{40}$ Hobbes states that "the state of nature is a state of war" in which "every man is an enemy to others". ${ }^{41}$ This state of war is a consequence of the anthropological estimation from which it starts to affirm a violent disposition of man: there exists "as a general inclination of the whole of humanity a perpetual and incessant desire for power that ceases only with death", and the struggle that arose from that eagerness makes men prone to enmity and war. ${ }^{42}$

One of the first tasks attributed to the modern state is to centralize power to avoid having in society multiple centers of power in tenacious rivalry by way of arms and bloodshed. The central power shall operate as the sole and exclusive power of attorney to administer and exert violence to deprive individuals or groups of their use in the solution of various disputes, prohibiting it in a general manner, with the dual objective of avoiding war and to prevent justice from being taken by their hand through individual, parental or clan revenge, with the free field for the law of the strongest. The provision on military means is reserved to the central power, which would have the power to use violence against individuals as a means to combat what they exercise and ensure a certain social order.

The Weberian concept of state implies, at least, three essential components: the territory, the legitimate monopoly of violence and domination. Although Max Weber does not seem to have any fixed reflection on the notion of territory, despite the innumerable references to the subject in his immense work, one can understand that the notion of territory - and its control - is a condition of State control of violence. Within a demarcated territory, the modern state is precisely the political community which removes

39 F. Cortés ROOAS, "La filosofía política del liberalismo. Hobbes, Locke y Rawls", en Estudios Politicos, núm. 10, Medellín, Instituto de Estudios Políticos de la Universidad de Antioquia, 1997, p. 61.

40 B. HRNDESS, "Ese dios mortal: Hobbes sobre el poder y el soberano", en Disertaciones sobre el poder. De Hobbes a Foucault, Madrid, Talasa, 1997, pp. 31-51.

41 Hobbes, 4, 139

42 Ibid, 115-116. 
the right of individuals to resort to violence as a form of resolution of their conflicts. Within modern society, therefore, there is no other particular group or community that is "entitled" to the use of violence as a form of conflict resolution in terms of interpersonal or intersubjective relationships, or even at the level of relations between citizens and the state. ${ }^{43}$

The consequences can be extracted from these ideas. In almost all the societies of the capitalist Western world, penal reform emerged as a requirement for modernization in the first half of the nineteenth century. Inspired by the Enlightenment philosophy of punishment, the reform provided for: (a) the state monopoly of legislative production and equality before the law; (b) State control of the territory, in the terms proposed by Max Weber; (c) the constitution and organization of police forces with the aim of preventing and repressing crimes committed, as well as proving the criminal responsibility of the accused within the limits of a given territory; (c) The organization of a judicial system capable of taking into account the responsibility for crimes as an individual responsibility, and imposing sanctions, in accordance with all legal requirements and criminal processes, according to the Aristotelian principle". ${ }^{44}$

\section{REFERENCES}

ADORNO, Sérgio, "Le monopole étatique de la violence : le Brésil face à l'héritage occidental", Cultures \& Conflits, V.59, automne 2005, p.6

Gewaltmonopol, available at: http://www.krimlex.de/artikel.php?BUCHSTABE $=\mathrm{G} \& \mathrm{KL} \_\mathrm{ID}=81,23.03 .2019$.

BOYAR, Oya, "Anayasa Hukuku ve Şiddet", MÜHF - HAD, C.22, S.1(61), https://dergipark.org.tr/tr/download/article-file/274328, 03.05.2020.

Colliot-Thélene, C., Violence et contrainte, Lignes, no: 25, mai 1995, p. 264-278.

ETTE, Otttmar, Europäische Literatur(en) im globalen Kontext. Literaturen für Europa; In: Özkai Ezli (Hrsg.): Wider den Kulturenzwang: Migration, Kulturalisierung und Weltliteratur; Bielefeld 2009; 257-296.

Deutscher Bundestag, Einsatz von privaten Sicherheitsfirmen im Hinblick auf das Gewaltmonopol, Ausarbeitung. WD 3 - 3000 - 236/12, 28. August 2012, s. 7.

"Das Gewaltmonopol des Staates in Abgrenzung zur sog., Leitkultur", Euradiopa, 24. JUNI 2017 , available

43 Adorno, 6.

44 Ibid, 7-8. 
Ankara Üni. Hukuk Fak. Dergisi, 70 (4) 2021: 1297-1312 State Monopoly Of The Right To Punısh ...

https:/euradiopa.wordpress.com/2017/06/24/kommentar-das-gewaltmonopoldes-staates-in-abgrenzung-zur-sog-leitkultur/, 14.06.2019.

FISAHN, Andreas, "Legitimation des Gewaltmonopols", Kritische Vierteljahresschrift, 2011, p. 4, available at: https://www.nomoselibrary.de/10.5771/2193-7869-2011-1-3/legitimation-des-gewaltmonopolsvolume-94-2011-issue-1, 12.06.2020.

GARCÍA, Gloria María Gallego, "Sobre el monopolio legítimo de la violencia", Nuevo Foro Penal, No: 66, 2003, págs. 72-120.

"Gewaltmonopol”, Kriminologie-Lexikon, Online, available at: http://www.krimlex.de/artikel.php?BUCHSTABE=G\&KL_ID=81, 23.06.2019.

GRUTZPALK, Jonas, "Das Gewaltmonopol des Staates", Bundeszentrale Für Politische Bildung, 14.6.2012, available at: https://www.bpb.de/politik/innenpolitik/innere-sicherheit/125721/dasgewaltmonopol-des-staates?p=all, 07.07.2019.

HAMMER, Felix, "Private Sicherheitsdienste, staatliches Gewaltmonopol, Rechtsstaatsprinzip und schlanker Staat", DÖV, 2000, S. 613.

HOBBES, Thomas, Leviathan, Çev. Semih Lim, 4. Baskı, YKY yay., İstanbul, 2004.

HRNDESS, B., "Ese dios mortal: Hobbes sobre el poder y el soberano", en Disertaciones sobre el poder. De Hobbes a Foucault, Madrid, Talasa, 1997, pp. 31-51.

"L'etat Détient Le Monopole De La Violence Légitime", La Philo, available at: https://a-philosophie.com/letat-detient-le-monopole-de-la-violence-legitimeweber, 26.06.2019.

MAKABENTA, Yen, "The death penalty and state monopoly of violence", The Manila Times, July 06 2019, available at: https://www.manilatimes.net/thedeath-penalty-and-state-monopoly-of-violence/273191/, 05.04.2019.

NISBET, Robert, "La formación del pensamiento sociológico", Amorrortu, V. 2, Buenos Aires, 1977 , https://www.amorrortueditores.com/Papel/9789505182244/La+formaci \%C3\%B3n+del+pensamiento+sociol\%C3\%B3gico, erişim tarihi: 20.03.2020.

Peilert, "Police-Private-Partnership", DVBl, 1999, 282 ff., 284.

ROOAS, F. Cortés, "La filosofía política del liberalismo. Hobbes, Locke y Rawls", en Estudios Políticos, núm. 10, Medellín, Instituto de Estudios Políticos de la Universidad de Antioquia, 1997, p. 61.

Saipa/Wahlers/Germer, "Gewaltmonopol, Gefahrenabwehrauftrag und private Sicherheitsdienste”, NdsVBl, 2000, 285 ff., (289-290). 
SANCAR, Mithat "Devlet Aklı" Kıskacında Hukuk Devleti, İletişim Yayınları, İstanbul, 2000.

Stober, "Staatliches Gewaltmonopol und privates Sicherheitsgewerbe - Plädoyer für ein Police-Private-Partnership", NJW, 1997, S. 889.

TÖNNIES, Sibylle, "Die "Neuen Kriege" und der alte Hobbes", Bundeszentrale Für Politische Bildung, 30.10.2009, available at: https://www.bpb.de/apuz/31632/die-neuen-kriege-und-der-alte-hobbes, 07.06.2019.

Walter, "Bekämpfung der Seepiraterie in: Die Polizei", BT-Drs., 2012, S. 1 (6); $15 / 5824$, S. 6.

WEBER, Max, Protestan Ahlakı ve Kapitalizmin Ruhu (Çev. Milay Köktürk), Bilgesu Yayınc1lık, İstanbul, 2000.

WEBER, Max, "Le savant et le politique", Union Générale d'Editions, Le Monde en 10-18, Paris, 1963, p. 29. 